\title{
FIFTH GRADE STUDENTS’ HOMEWORK OVERLOAD
}

\author{
Behxhet Gaxhiqi ${ }^{1}$ \\ Shefqet Mulliqi \\ ${ }^{1 / 2}$ University of Gjakova "Fehmi Agani”, Gjakova-KOSOVO
}

\begin{abstract}
This study analyses the burden which fifth grade students' homework brings. We were assigned to do a research on this issue due to its being quite recent, and along our experience we encountered on a lot of discussion with parents, teachers, and also with the students themselves, regarding the burden that homework show. The sample of the study consisted of 60 students of the 5th grade of the elementary school of Dardania in Prishtina. The questionnaire included four types of questions of the scientific research, comprising of exploratory, descriptive, explanatory, and evaluation questions. This study belongs to the methodology of quantitive research, where the measurement instrument is the questionnaire.Homework have their own impact, but considering the plan program, which is overloaded, it is really difficult for children if the homework is not well explained by the teacher using two or three examples in the class, and then at home too. There are similarities between classwork and homework, it's just the numbers that change, but if the student has not achieved to comprehend it, or if the teacher was not able to simplify it, then the child will have difficulty in doing that homework. Research found out that students finish their homework better when they're at home, in a more efficient way, around $65 \%$ of them. Whereas $35 \%$ of them are overloaded everyday with homework.
\end{abstract}

Key words: students, homework, priorities, teachers, parents, etc

\section{INTRODUCTION}

The impact of homework on students' achievement is a widely discussed topic in our schools today and beyond.Homework is typically defined as any tasks"assigned to students by school from the teachers, meant to be carried out during non-school hours" (Cooper,1989,7). The impact of homework on students' achievement is an important topic, knowing that the main goal of the teacher is for students to be successful and have an impact in the world. The amount of tasks, how often they should be given, and what they should contain are all issues that researchers of the relationship between homework and students' achievement try to address. And this is exactly the focus of this study, of how doing and correcting homework affects students' achievement in their subject during the lesson. "Students in Kosovo do not spend enough time in school, so in such situation, they cannot acquire all the knowledge and all the skills they need to acquire during school hours. And, that is why in our schools there is the habit of giving homework, and why many times the amount of homework and their nature requires a huge commitment of students at home ", Pupovci estimates. 2018.

Overloaded curriculum. Nysrete Shkodra, a teacher, also talks about the overloaded curriculum and the difficulties that can be presented to students. "Homework has the effect of itself, but considering the curriculum, which is overloaded, it is very difficult for children if those tasks are not explained very well with two or three examples by the teacher in class, and then at home too. There are similarities about classwork and homework, only the numbers change, but if the student has not managed to understand or if the teacher has not managed to simplify, then that child will find it very difficult to do that task at home ", Shkodra says. 2020 
ISSN 2661-2666 (Online) International Scientific Journal Monte (ISJM) DOI: 10.33807/monte.20211831 Volume 4, (No).1 (2021): April

While referring to Paschal etal. (2001) the amount of encouragement that students have for homework affects their achievement in school up to 50\%."Homework is a way to increase students' commitment to school subjects and to promote their success. Homework that is well structured and well planned is the most effective " (Ellsasser, 2007). Their purpose should be very clear to all students so that they understand how these tasks will help them to succeed. The effect of homework is still a datable issue. In general, homework does not improve the learning performance of students (children) but may improve some of the academic skills of older students, especially in students with a low grade point average. Homework can also be stressful for pupils, students and their parents by reducing students' free time or time devoted to other activities such as exercises, playing, working, sleeping, etc. Epstein, Joyce L.; Voorhis, Frances L. Van (September 1, 2001)

\section{But, what revolves students or parents about homework?}

According to several surveys conducted by various studies on this topic, students complain about the duration of homework, the repetition of the same exercises to which they do not they no longer have any interest in, the great difficulty in some cases, which makes them 'hate' homework, their repetitive character, of memorization or in other words not at all creative, of the obstacle they cause in the development of other activities such as social activities, artistic, sports or entertainment. Mustafa, Avzi.2002. Parents on the other hand complain about the difficulty in understanding their children's homework and the inability to help them, little time available to help children due to work and extended hours, tiredness or even the desire to see children being more active.www.portalishkollor.al

By,preparing students for independent work we manage for them not to just be passive consumers of knowledge provided by the teacher.(Z.Nijazi, 2005).

Teaching work as one of the most organized, but also the most complex educational activities, within the didactic organization, includes the tasks of students in school and at home. Students' homework differs from classwork because it takes place outside of the school, without the direct participation of the teacher. The main feature of these tasks is the engagement of students' independent work in doing them. The content and character of homework includes all elements of teaching work. (TH.Karaj.2014).

Homework is found in relationships of dependence and mutual relationship with teaching work. They are an integral part of learning because they are derived from regular learning and in special cases, they can also precede the lesson, especially when it comes to summarizing the various content or the preparations that students have to make in advance. Like any other activity in teaching work, homework must be done at a high level of planning and organization. Homework accompany these requirements until the stage of their examination and assessment.

(G. Behxhet.2019)

Research Problem.General research problem is that: How much are the first grade students loaded with homework, and how difficult and overloaded they are for the age of these first graders.

Sub-problems of research are followed by the questions as below:

1. How much irritated do you get when teachers give you homework every day?

2. How do parents react when their children do not want to finish their homework?

3. Does homework have a positive impact on children?

4. How much time do you need to finish your homework? 
ISSN 2661-2666 (Online) International Scientific Journal Monte (ISJM) DOI: 10.33807/monte.20211831 Volume 4, (No).1 (2021): April

\section{METHODS}

This study uses quantitative research methods where the instrument is the questionnaire.The researcher collects and analyzes the quantitative data.The quantitative data and their subsequent analysis provide a general understanding of the research problem.

a) Aim of the study: The purpose of this study is to familiarize students with homework and the burden of these tasks they present to students, in the classroom and at home.

b) Study group: The study group that refers to is the involvement of the students of grades $5^{\text {th }}$ grades of primary and lower secondary schools in Kosovo, specifically in the school of Dardania in Prishtina. The age of the children (students) is 10 years old.

c) Data collection: The research was done through a questionnaire, where the questionnaires are dedicated to the parents of the children, as they are directly related to their children

d) Data analysis: Data were analyzed by descriptive statistics. IBM-SPSS Statistics 20 was used for quantitative data analysis.

FINDINGS :Findings are expected results of our research. They are presented through two tables and two figures providing answers to the four research questions.

Table 1. In the first question: How often do you think homework should be given?

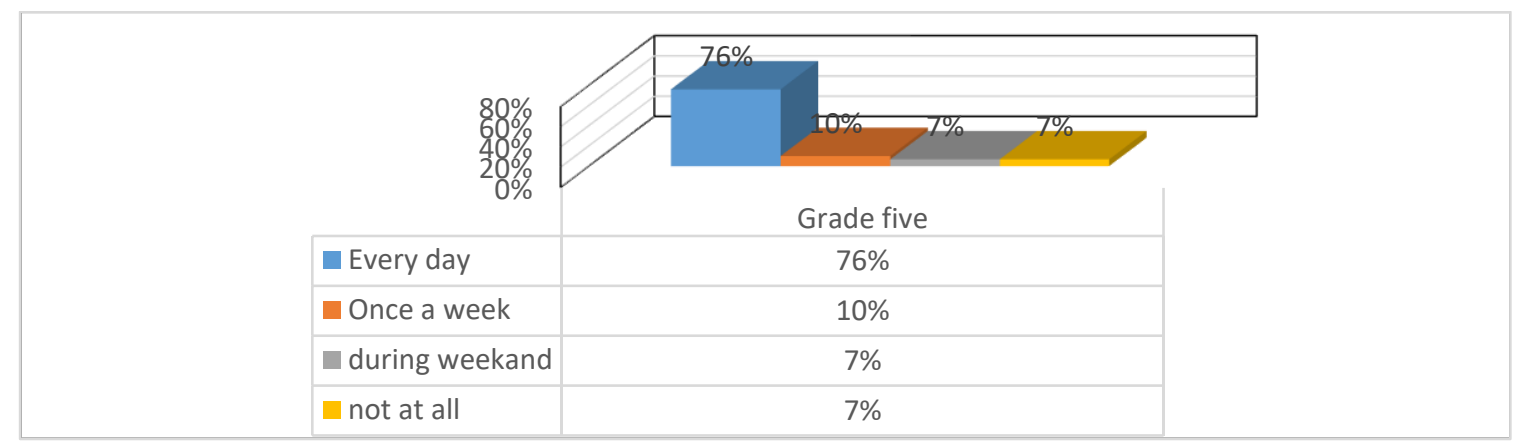

Graph 1.The opinion of students about how often they should be given homework.

From the percentage presented in Graph 2, students require to have homework every day.So $76 \%$ of them answered that they should have homework every day, $10 \%$ of them answered that they should have homework once a week and the same percentages were with those on the weekends and not at all, so $7 \%$ of them answered that they should have homework only on weekends and also $7 \%$ of them answered that they should not have homework at all.

\section{Research question 2. How often do you seek help from others for homework?}


ISSN 2661-2666 (Online) International Scientific Journal Monte (ISJM) DOI: 10.33807/monte.20211831 Volume 4, (No).1 (2021): April

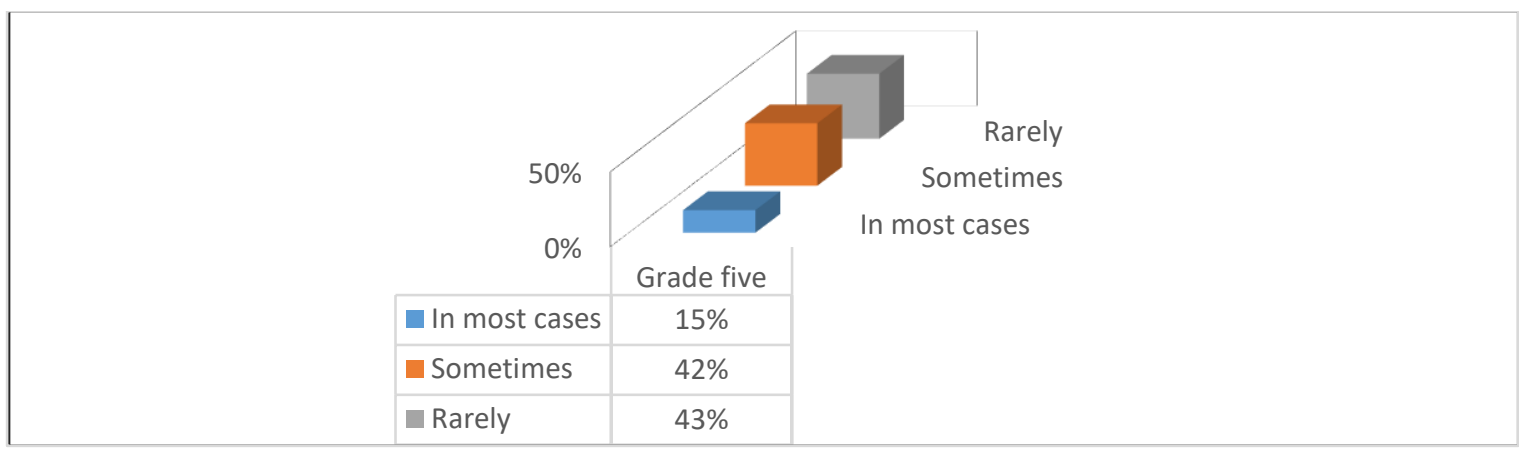

Graph 2. Has to do with the help students seek from others for homework..

From the percentage presented in Graph 2, students rarely ask for help from others to do their homework, but this percentage is close to the answer "sometimes", so in some cases they ask for help. So $43 \%$ of them answered that they very rarely ask for help from others to do their homework. $42 \%$ of them said that they sometimes ask for help when needed or when they encounter difficulties and only $15 \%$ responded in most cases seeking help.

a) Research question 3: How much time do you need to finish your homework?

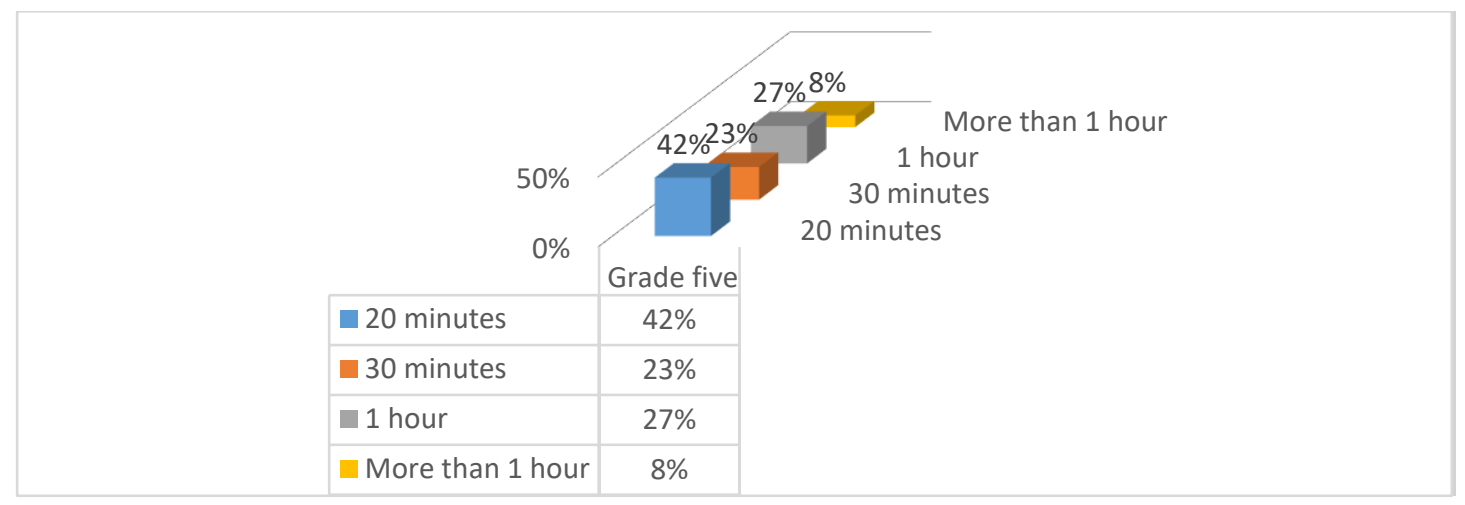

Graph 3. The time students need to finish their homework.

The percentages which are presented in graph 3, show us best that students finish homework for a short time, so 20 minutes. Thus, they do not need long time for their performance. So $42 \%$ of them answered that they do their homework for a short time, 20 minutes, $23 \%$ of the students answered that they do their homework for 30 minutes, $27 \%$ of students answered that they did their homework for a longer time, so 1 hour, and only $8 \%$ of them answered that they finished it for more than 1 hour, so a much longer time.

Research question 4: In which subject do you do your homework most willingly?

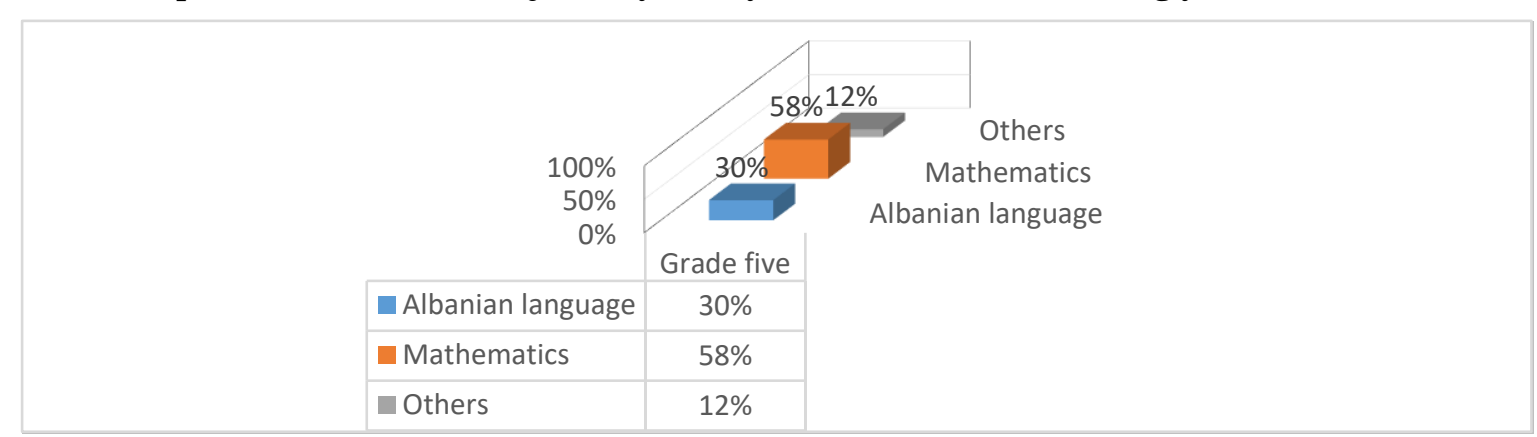

Graph 4. In which subject students do their homework more willingly. 
ISSN 2661-2666 (Online) International Scientific Journal Monte (ISJM) DOI: 10.33807/monte.20211831 Volume 4, (No).1 (2021): April

From the percentages presented in Graph 4, it is clear that students have a greater desire for the subject of Math than for other subjects for doing homework. So $58 \%$ of them answered that the subject they most willingly did their homework was Math, $30 \%$ of the students answered they did their homework more willingly in the subject of Albanian language, and only $12 \%$ of them answered that in other subjects, such as Man and Nature, Figurative Art, etc. they did their homework more willingly. So in a high percentage Math remains the favorite subject of first graders and which they prefer more to do their homework.

d) Research question 5: How tiring is homework?

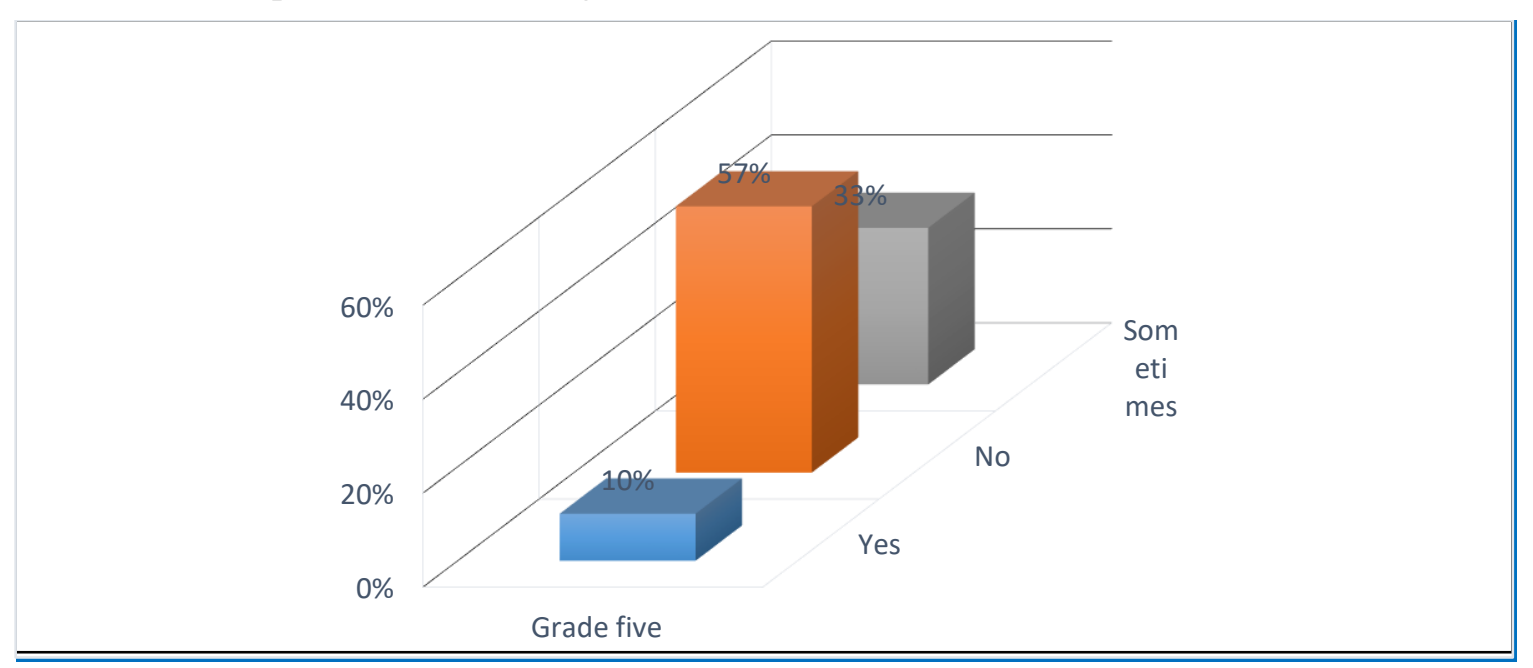

Graph 5. Tirendess that homework present for fifth grade students.

From the percentage presented in Graph 5, students do not show any tiredness while doing homework, so they are not tiring. Thus, $57 \%$ of them answered that homework for them is not tiring, so they perform homework without showing obvious tiredness, $33 \%$ of students responded that homework for them is sometimes tiring, so they take some breaks during their performance, and only $10 \%$ of students answered that homework according to them was tiring, so that they often asked for breaks. So based on the graph, it is clear that a higher percentage show that homework for first graders is not tiring.

e) Research question 6: On what level of difficulty is homework at?

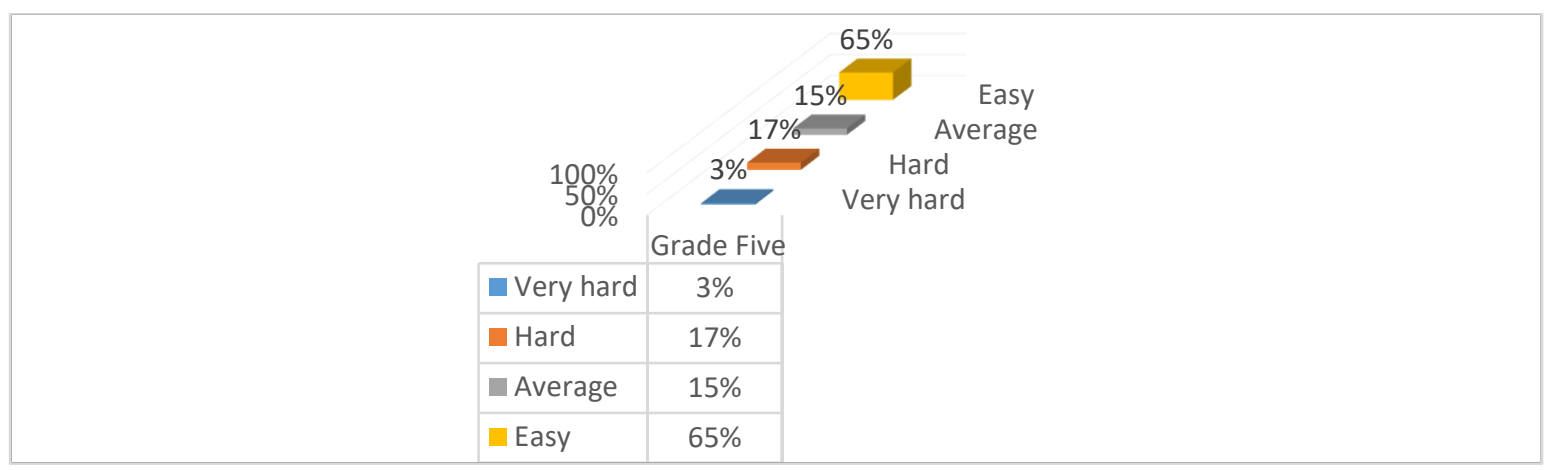

Graph 6. Has to do with the level of difficuty that homework present for fifth grade students

From the percentage taken out in Graph 6, we notice that homework is not difficult for first graders, so they are easy in a high percentage. Thus, $65 \%$ of them answered that they were easy and did not present any difficulty, $15 \%$ of them answered that homework for them was of medium difficulty, so neither easy nor difficult, $17 \%$ of 
ISSN 2661-2666 (Online) International Scientific Journal Monte (ISJM) DOI: 10.33807/monte.20211831

Volume 4, (No).1 (2021): April

them answered that they were difficult, that is, they required more dedication to perform them, and only $3 \%$ of them answered that homework was too difficult for them, so they could not perform it without the help of someone else. So, the highest percentage is that they are easy and do not pose any problem for them.

\section{DISCUSSION and CONCLUSION}

John Hattie's research show that homework has no effect on elementary school students' grades. So do not give homework, right? I do not agree with his obvious reasoning that we can change, not to eliminate homework, because it is a sign of quality from parents, I think we should see it differently. Homework definitely affects the expansion of wisdom, knowledge and should come from planned work with curriculum. Cooper, H. (1 989).

Homework, in order for students to succeed, depends, first of all, on the fact that how is the teaching developing, respectively the school subject. Teachers must be careful that the homework is given according to the planning need, and more according to the abilities of the students at work. Sh, Osmani:(1983. Tasks should start from the known to the unknown or from the concrete to the abstract, because only such a method of learning encourages the student for independent and productive work. Geide-Stevenson, D. (2009).

Students need to understand that homework can help them be academically successful and grow intellectually. As well, homework has a high number of benefits outside the educational part too; which promote student independence and accountability. It is important to continue the discussions and find methods that greatly influence the achievements of our students. Paschal, R.A., Weinstein, T., \& amp; Walberg, H.J. (2001). Many measures and strategies must be undertaken to make this happen. And it is very important to emphasize that teachers should educate students in the spirit that their homework is of more value, rather than just a school obligation.

When assigning homework, the M.L. teacher should consider the following recommendations:

$>$ Considering how much time the student needs to spend on homework and the fact that there are some subjects to prepare for and not just your subject.Give students homework guidance and make sure they understand the instructions.

$>$ Allowing students to start homework in the classroom in order to observe the way they do it and how they do it. Cooper, H.(1 989).

$>$ Getting homework back as soon as possible.

$>$ Not putting pressure on the assessment. Educating students with the idea that the purpose of homework is to reinforce the teaching knowledge and develop academic achievement. Cooper,H.1991.

$>$ The way the teacher offers a variety of exercises in cases where the learning topic is of a high difficulty leaving it up to the students to choose which one to perform;

Assigning homework for each level of learning difficulty;

$>$ Giving practical assignments, where students manage to combine learning knowledge with problems from everyday life, should be spread to other teachers and be seen as examples of methods to be incorporated during the homework process. Pasi,R.J. (2006). 
ISSN 2661-2666 (Online) International Scientific Journal Monte (ISJM) DOI: 10.33807/monte.20211831 Volume 4, (No).1 (2021): April

\section{REFERENCES}

Anita,Woolfolk.(2011).Psikologji Edukimi. Tiranë.

Gaxhiqi,B.(2019).Mësimi i Diferencuar në shkallë të ndryshme të vështirësive në mësimxënie.Tiranë.

Anderson, G., Beniamin, D., \& M. Fuss. (1994). The determinants of success in university introductory course.

Bora. H.(2018).Vlerësimi i detyrave të shtëpisë ndikimi i tyre në arritjet akademike të nxënësit.

Cooper, H. ( 1 989). Synthesis of research on Homework. Educational Leadership

Zylfiu,N.(2005).Didaktika. Prishtinë.

M,Bardhyl.2015.Metodologjia e mësimdhënies.

Cooper, H. 1991. Homework. Feelings and Their Medical Significance

Cooper, H .1991 Homework Research and Policy

Darling-Hammond, L., Olivia, I. (2006). If They'd Only Do Their Work! EducationalLeadership

Geide-Stevenson, D. (2009). Does collecting and grading homework assignments impactstudent

Dituri shoqërie, për klasën V të shkollës fillore, (koautor V. Nedoviq), Prishtinë, 1976, f.1-160.

Paschal, R.A., Weinstein, T., \& Walberg, H.J. (2001).The effects of homework onlearning:A quantitative synthesis.

Pasi, R.J. (2006). Homework That Helps. Principal Leadership

Xh.Murati.2002. Didaktika (Metodologjia e mësimdhënies), Tetovë

A.Mustafa.2002. Didaktika e gjuhës shqipe dhe e leximit letrar, Shkup

Osmani, Shefik. 1983.Fjalor i pedagogjisë, Tiranë

Pedagogjia II, në red. P. Shimlesha, Prishtinë, 1977

Pedagoška enciklopedia I dhe II, Beograd, Zagreb, 1989

Z,Nijazi. Didaktika ,2005.Teoria e mësimit dhe e mësimdhënies, Prishtinë.

Grup autorësh: Didaktika. Instituti i Studimeve Pedagogjike. Tiranë. 1986. 348 faqe.

G Mialaret:(1997), Pedagogjia e përgjithshme, Koha, Prishtinë

H, Koliqi:(1997, 1998), Historia e pedagogjisë botërore I dhe II, Universiteti i Prishtinës, Prishtinë.

H, Koliqi:(2002, 2004), Historia e arsimit dhe e mendimit pedagogjik shqiptar, Prishtinë - Tetovë, OCLC 163636435 ISBN 9951-07-084-1

M, Kraja:(1998, 2006), Pedagogjia, Tiranë. 